\title{
Whither justice? An analysis of local climate change responses from South East Queensland, Australia
}

\author{
Diana MacCallum \\ School of Built Environment, Curtin University, GPO Box U1987, Perth 6845, Australia; \\ e-mail: diana.maccallum@curtin.edu.au
}

Jason Byrne

School of Environment, Building G31, Griffith University, Parklands Drive, Southport, Queensland, Australia; e-mail: jason.byrne@griffith.edu.au

Wendy Steele

Urban Research Program, Griffith University, 170 Kessels Road, Nathan, Queensland, Australia; e-mail: w.steele@griffith.edu.au

Received 15 November 2011; in revised form 6 September 2012

\begin{abstract}
Climate change is a highly contested policy issue in Australia, generating fierce debate at every level of governance. In this paper we explore a crucial tension in both the policy and the public debate: a seeming lack of attention to social inclusion and broader equity implications. We pay special attention to the municipal scale, where concerns about social difference and democratic participation are often foregrounded in political discourse, using South East Queensland - a recognised climate change 'hotspot' - as a case study. Mobilising critical discourse analysis techniques, we interrogate three local government climate change response strategies, and place these in the context of transscalar discourse networks which appear to sustain a technocratic, 'ecological modernisation' approach to the issue. Finally, we suggest a broad strategy for reimagining this approach to embed a notion of climate justice in our policy thinking about climate change.
\end{abstract}

Keywords: climate change, social justice, climate justice, local government, Australia

\section{Introduction}

Recognition of the risks posed by climate change - most obviously a rise in sea level, increased frequency of severe weather events, and the resulting marginality of certain industries - has led to a flurry of policy activity in Australia (Steele and Gleeson, 2010). This activity has generated climate change response strategies, action plans, and regulatory guidelines at every level of government, accompanied by vigorous, often rancorous, debate about the likely effectiveness of proposals, their potential impacts on business (and thus economic growth), public budgets, and government liabilities, with the associated question of 'who should pay for pollution?' What seems to be missing from most of the debate, though, is explicit consideration of how relevant interests and impacts differ across social groups and communities, and the important implications of this fact for social justice. This is puzzling, given growing evidence that climate change will disproportionately impact communities who are already socioeconomically vulnerable and politically marginalised (for example, Campbell et al, 2008; Conner, 2008; Demetriades and Esplen, 2008; Ford et al, 2008; Furgal and Seguin, 2006; Green and Preston, 2006; Harlan et al, 2008; Mendelsohn et al, 2006). What are the reasons for this gap? And what does it mean for policy?

At the local government level these questions have particular significance. Although local policy is constrained - indeed, partly dictated - by that of higher levels of government, it needs also to respond to the realities of life at the local, neighbourhood, and household 
scales: where personal identities, relations, and differences are foregrounded, and where individuals are more likely to demand a voice in relation to their own interests (Bulkeley, 2000a). The question we ask in this paper, therefore, is how local climate change responses can balance the received scientific and macroeconomic discourses that seem to shape national and state initiatives; first, with locally specific understandings of the problem and, second, with localised concerns about equity and inclusion.

Our starting point for exploring this question is a critical analysis of three local climate change action plans/strategies in the Australian region of South East Queensland (SEQ) - a recognised climate change 'hotspot' (Garnaut, 2008; IPCC, 2007) due to its coastal location, its subtropical climate, and its status as the fastest-growing region in Australia. ${ }^{(1)}$ We focus in particular on the tensions and related potentials between the 'global' policy objectives of climate change mitigation/adaptation and the 'local', but no less important, one of contextually relevant social inclusion, highlighting how these objectives, tensions, and potentials are or are not discursively realised within the local policy documents. Few analyses of this type have been undertaken at the local scale, creating a knowledge gap with important implications for our ability to recognise and resolve such tensions, or to respond to related opportunities for urban and environmental governance [Amundsen et al, (2010) and Fisher (2012) are notable exceptions]. In the following section we tease out these issues with reference to recent debates on social inclusion and climate change governance. After a brief explanation of our methodology, a form of critical discourse analysis, we then describe the transscalar institutional environment for local climate change policy in SEQ before outlining the key findings from the analysis of the documents within this context. A discussion of the significance of these findings informs our concluding remarks.

\section{Social inclusion and climate change: scaled discourses of governance}

The Australian Commonwealth Government defines social inclusion as a condition wherein "Australians feel valued and have the opportunity to participate fully in the life of society" (Commonwealth of Australia, 2012a). In their analysis, social inclusion has four dimensions: opportunities for education and training, workforce participation, ability to engage with people and draw upon community resources, and opportunities to participate in decision making. These dimensions are operationalised and measured through a range of indicators, including: employment; income; civic engagement; housing; exposure to domestic violence; health status; life expectancy; literacy and numeracy; access to the Internet, public transport and other services; and crime and security (Commonwealth of Australia, 2012b). As the breadth of these indicators suggests, social inclusion is a rather imprecisely defined concept, but one which denotes important interrelationships between several different theoretical constructs - accessibility, labour markets, social capital, and civic participation, among others (Capetola, 2008; Green et al, 2012; Lucas, 2006). In particular, it acknowledges that access and participation are constrained by socioeconomic and personal factors including age, disability, education, and livelihood (Lucas, 2006).

We hold that social inclusion is an important consideration in climate change policy because it shapes not only the vulnerability of individuals and populations but also their

${ }^{(1)}$ Climate change hotspots are places on the planet where the impacts of climate change will be experienced strongest (Kerr, 2008). The concept has both vulnerability and climate response dimensions: the former indicating where impacts on biophysical or socioeconomic systems will be felt harder, and the latter referring to regional climatic sensitivities to global environmental change (Giorgi, 2006). Often, hotspots are identified at a national or a continental scale. Climate models are used to show where temperature and precipitation changes will occur. These models identify trends such as drying and warming, which in turn are translated into ecosystem impacts (Hughes, 2011) and impacts on human populations, infrastructure, and livelihoods (Evans, 2008; Patz and Kovats, 2002). 
ability to undertake and participate in climate change adaptation responses. Vulnerability to current and future climate change impacts is not simply about direct exposure to harm; it is also a function of knowledge of potential harms, ability to cope with change, capability to access support, and capacity to adapt (Paolisso et al, 2012). For example, climate change is expected to bring increases in water, food, and energy prices, and vulnerable populations will be hit hardest by these price increases. But often these populations are also marginalised in decision making, and seldom have a voice in shaping policy. Where policies do consider such groups, they rarely consider options for empowerment or building adaptive capacity, and instead focus on emergency response, welfare provision, handouts (eg, compact fluorescent bulbs), and tokenistic forms of consultation (Capetola, 2008).

Few et al (2007) caution that social inclusion in climate change response entails more than simply consulting a broad range of stakeholders. As Rydin and Pennington (2000) argue, simply increasing consultation will not guarantee better policy outcomes; rather, processes should seek to reduce barriers to involvement and building social capital, accommodate dissent, and minimise rent-seeking by special interest groups. ${ }^{(2)}$ This implies active inclusion of local "knowledge, opinions and aspirations" (Few et al, 2007, page 48; also see Green et al, 2012). Critical here is the notion that adaptive responses must be tailored to "local needs and resources" (Few et al, 2007, page 48) in addressing this "profoundly local issue" (Bulkeley and Betsill, 2003, page 2). This draws our attention to the municipal level, where local needs and resources may be identified quite specifically, allowing policy to respond appropriately and inclusively to local patterns of vulnerability (Aylett, 2010; Rutland and Aylett, 2008). But, as many authors have noted, the capacity of local authorities to do this is significantly complicated by conditions and discourses surrounding - or 'framing' - the support municipalities receive from government and networks at higher scales, particularly in the forms of funding, knowledge, and policy environment (eg, Amundsen et al, 2010; Betsill and Bulkeley, 2006; Bulkeley and Betsill, 2003; Fisher, 2012).

O'Brien et al argue that "discourses and framings of climate change do matter" (2007, page 74 , original emphasis):

"framing of an issue creates boundaries around social groups, biophysical entities, or their interactions ... [influencing] the questions that are asked ... the kind of knowledge that is produced ... what is included on the agenda, and what is silenced. Framings emerge from discourses that are embedded in institutions, actors and academic disciplines" (page 76). Understanding how key concepts - such as 'climate change', 'vulnerability', and 'local needs' - are interpreted and mobilised for particular purposes is therefore an important task.

A number of authors have identified, for example, a profound tension between technocratic modes of representing climate change vulnerability and discursive agendas centred on social and/or ecological justice (eg, Bailey and Wilson, 2009; Curran, 2011; O'Brien et al, 2007): a tension which can have important material consequences. ${ }^{(3)}$ O'Brien et al (2007) assert that 'vulnerability' in the climate change literature is typically framed in one of two distinct waysend point or 'outcome vulnerability' and starting point or 'contextual vulnerability'. Outcome vulnerability is the product of scientific analyses (eg, scenario development, modelling)

${ }^{(2)}$ We note that such aims can be problematic. In Australian society there is still some degree of scepticism about the seriousness of climate change, and some mistrust of both climate scientists and decision makers (Buys et al, 2012; Pietsch and McAllister, 2010). This is partly the result of interestbased politics, where vested interests have driven a reactionary stance to climate change by a vocal minority (Bulkeley, 2000b). Participatory processes need to recognise public opposition to strategic climate responses without allowing dissent to derail or hijack decision making.

${ }^{(3)}$ Curran (2011) attributes the 2010 downfall of Australia's Prime Minister Kevin Rudd in large part to this tension; in particular, his election rhetoric about climate change as a 'moral' issue of global justice stood in stark contrast to the technocratic nature of the policies enacted under his leadership. 
which identify the "net impact of the climate problem" (2007, page 75) as a future condition, typically couched in financial, cost-benefit, ecosystem damage, or human mortality terms. The 'contextual' framing, on the other hand, construes vulnerability as "a present inability to cope with external pressures or changes" (2007, page 75 ), which will be exacerbated by climate change. Within this framing, climate change is seen as a 'transformative process' that affects different people in different ways; vulnerability is a "characteristic of social and ecological systems ... generated by multiple factors and processes" (2007, page 75). Developing policy according to the outcome vulnerability frame implies a 'broad-brush' approach to assessment in which it is difficult to pinpoint particular vulnerable people or groups due to problems with data availability and large-scale modelling — an issue identified by Crick et al (2012) in their hotspot vulnerability assessment for SEQ. A contextual framing, taking vulnerability as a starting point, would rather entail changing the social context - the prevailing political, economic, social, technological, and institutional relations - in which vulnerability to climate change is shaped, in order to enable people to respond better to impacts (O’Brien et al, 2007). This would be a social inclusion approach.

To understand how local climate change responses are shaped by these wider discursive framings requires close attention to their content, structure, and language. To this end, we apply a form of critical discourse analysis (CDA).

\section{Critical discourse analysis}

CDA refers to a broad suite of approaches which use detailed analysis of texts to elucidate social practices. In this tradition, texts are treated as realisations of - and therefore as hard evidence for-discourses and practices that serve to (re)produce ideologies and social relations (Chouliaraki and Fairclough, 1999; Fairclough, 1995; 2003; Weiss and Wodak, 2003). The aim of CDA, as Jacobs states, is to "interrogate the ways in which key actors deploy specific terminology either in written or spoken form within a wider social and political context" (2004, page 819). That is, text analysis is not an end in itself, but a useful point of entry to understanding social institutions, social change, and the knowledge and power relations that underlie these phenomena (Mills, 1997; Stibbe, 2001). This approach (not always named as such) has been applied with some success in urban and environmental policy research to shed light, first, on the contexts in which policy documents were developed or framed and, second, on the narratives used in their construction - in particular, as the outcomes of struggles over truth claims and/or other forms of power (eg, Collins, 1999; Hastings, 1999; Hillier, 1999; Jacobs, 2004; Kumar and Pallathucheril, 2004; MacCallum, 2008; 2009; MacCallum and Hopkins, 2011; Myerson and Rydin, 1996; Portugali and Alfasi, 2008; Tett and Wolf, 1991; Throgmorton, 1996; 2000).

For our purposes we wish to explore: firstly, how local policy documents construe relationships between climate change and local people; secondly, whether inequities in social relations feature in their analysis; and, thirdly, whether they are inclusive towards local forms of knowledge and agency. These aims may be broken down into the following analytical questions:

(1) How is climate change framed as a local issue?

(2) How are local people framed in relation to climate change?

(3) How are social relations invoked?

(4) What forms of knowledge (and knowledge production) are drawn upon?

(5) Where and how does the text situate the power to act (agency)?

Mills (1997) has noted that statements and/or arguments take place within a broader, power-laden context of other arguments, constrained by sets of rules. We can understand this fact in terms of dialogicity, a crucial feature of texts (Bakhtin, 1981). Frames and meanings 'travel' from one arena/context to another, from one phase of a policy process (for example) to 
another, each recontextualisation translates them: meanings are built upon, subtracted from, reconfigured as they move through the administrative and political machinery (Fairclough, 2003; Muntigl et al, 2000; Wodak, 2009). This is a particularly important aspect of the networking of institutions (Fairclough, 2005), shedding light on the relationship between received discourses - for example, those circulating at the global, state, and national levelsand their manifestation in, particularly, local policies. For this reason, we add one further question to guide our analysis of the documents:

(6) What other texts - or intertexts - does this text respond to, and how?

Kumar and Pallathucheril are critical of many studies employing CDA because "we are not told how texts are analysed, understood, and assessed" (2004, page 830). Our own approach draws on Halliday's (1978) theory of language as a 'social semiotic', as a system for building and exchanging social meanings. Halliday's (1985) systemic functional grammar (SFG) analyses language in terms of three distinct functions and the 'metafunctional' resources that its speakers can choose from to realise these: the construction of ideational meanings (about the world); interpersonal meanings (relations, orientations, and identities); and textual meanings (organisation of information). This framework has been popular with CDA practitioners (eg, Fairclough, 1989; Martin, 2004; van Leeuwen, 1993) because of its capacity to dig beneath a text's surface content and expose the means by which relations and forms of organisation are constructed in discourse. Table 1 summarises - in drastically

Table 1. Systemic functional grammar (SFG) resources addressing analytical questions.

\begin{tabular}{|c|c|c|c|}
\hline Question & Ideational & Interpersonal & Textual \\
\hline (1) Climate change & $\begin{array}{l}\text { lexical relations } \\
\text { (what is the text 'about') }\end{array}$ & & $\begin{array}{l}\text { thematisation } \\
\text { (positioning for } \\
\text { emphasis and } \\
\text { indication of assumed } \\
\text { knowledge) }\end{array}$ \\
\hline (2) Local people & $\begin{array}{l}\text { lexical relations } \\
\text { transitivity } \\
\text { (who does what to whom?) }\end{array}$ & & thematisation \\
\hline (3) Relations & transitivity & $\begin{array}{l}\text { mood/exchange } \\
\text { (what are the roles of } \\
\text { audience and author, in } \\
\text { what sort of interaction?) } \\
\text { appraisal } \\
\text { (construal of affect, } \\
\text { certainty, judgment, and } \\
\text { identity) }\end{array}$ & thematisation \\
\hline (4) Knowledge & $\begin{array}{l}\text { logical relations } \\
\text { (how are things and } \\
\text { phenomena connected?) }\end{array}$ & appraisal & $\begin{array}{l}\text { method of } \\
\text { development } \\
\text { (structure of } \\
\text { argument) }\end{array}$ \\
\hline (5) Agency & transitivity & mood/exchange & \\
\hline (6) Intertexts & $\begin{array}{l}{ }^{\mathrm{a}} \text { direct reference; } \\
{ }^{\mathrm{b}} \text { conventional discourses } \\
\text { (representation of } \\
\text { substance) }\end{array}$ & $\begin{array}{l}{ }^{\mathrm{b}} \text { style } \\
\text { (authorial identity) }\end{array}$ & $\begin{array}{l}{ }^{\mathrm{a}} \text { thematisation; } \\
{ }^{\mathrm{b}} \text { generic structure } \\
\text { ( structure of social } \\
\text { practice or argument) }\end{array}$ \\
\hline
\end{tabular}

Notes. Blank cells indicate that we did not consider the question in relation to the dimension, italics introduce each new SFG term.

${ }^{a}$ explicit - indicated by direct reference to other texts;

${ }^{b}$ subtle- how present text implicitly draws on conventional discourses, styles, generic features. 
simplified form - some key potentials of SFG in relation to our questions. The SFG jargon is explained within the table where each term first appears in italics. Blank cells indicate that we did not consider the question in relation to that dimension. In addition, the intertextuality question is broken down into two aspects: (a) an explicit one, indicated by direct reference to other texts; and (b) a more subtle one focused on how the present text implicitly draws upon conventional discourses, styles, and generic features [Fairclough's (2003) 'orders of discourse'] of other texts circulating in this area of governance.

It is not our intention to suggest that text analysis can present a complete picture of the social and institutional processes through which documents are developed; nor that there is a simple one-to-one correspondence between the documented policies of an organisation, its values, and its material strategies (Green et al, 2012; Richardson and Jensen, 2003). However, we do see published texts as a useful point of entry to understanding the transscalar institutional conditions shaping local capacity to act: they work to reproduce the legitimacy and authority of certain framings and strategies and, conversely, to marginalise framings and interests that they ignore.

\section{Climate change policy and local government in SEQ}

The Australian region of SEQ has been identified as a climate change hotspot (Garnaut, 2008; IPCC, 2007) because changes in temperature and rainfall are expected to impact water supplies; heighten vulnerability to flooding; and potentially increase bushfires, heatwaves, and insect-borne diseases (Crick et al, 2012; Hennessy et al, 2007). The region is characterised by coastal urban sprawl, rendering it more susceptible to coastal erosion and flooding associated with rising sea levels and storm surge from more intense seasonal weather systems, and concomitant property damage and loss of life. This produces significant challenges not only for urban and environmental management but also for social equity - for example, in relation to housing costs and security (Barnett, 2003; Steele, 2010; Steele and Gleeson, 2011), socioeconomic polarisation (Baum et al, 2009), and vulnerability to increasing energy prices (Dodson and Sipe, 2008a; 2008b).

The documents that we focus on for the purposes of this paper are the climate change response strategies by three coastal local governments in SEQ: the cities of Brisbane, Gold Coast, and Redland (figure 1). The City of Brisbane is responsible for managing most of Brisbane's metropolitan area, population 1 million, and is the largest and most powerful local government authority in Australia. Like any large city, Brisbane is very socially diverse. The City of Gold Coast governs a $57 \mathrm{~km}$ stretch of coastline containing some of the fastest growing urban areas in the country, with an economy largely dependent on tourism. Redland City is a smaller, but still rapidly growing, municipality on the outskirts of the Brisbane conurbation, whose area or authority crosses Moreton Bay from middle-class outer suburbs to the far more economically dependent communities on North Stradbroke and smaller islands.

The institutional context for the production of these documents is complex, involving multiple scales of governance and a variety of obligations and constraints [Amundsen et al, (2010) show similar issues in Norway]. Australia is signatory to international agreementsmost importantly, the United Nations Framework Convention on Climate Change, the Kyoto Protocol of 1997, and the Copenhagen Accord of 2008 - which frame obligations in relation to climate change at the national scale. Commonwealth directives strongly shape state policies and strategies, which in turn place constraints on local ones. But local governments are also directly involved in national and international networks and, during the late 1990s-2000s especially, while Australia was not a signatory to the Kyoto Protocol, much of the initiative on climate change policy was being undertaken by local municipalities under the auspices of Agenda 21, and often with support and/or encouragement from ICLEI-Local Governments 


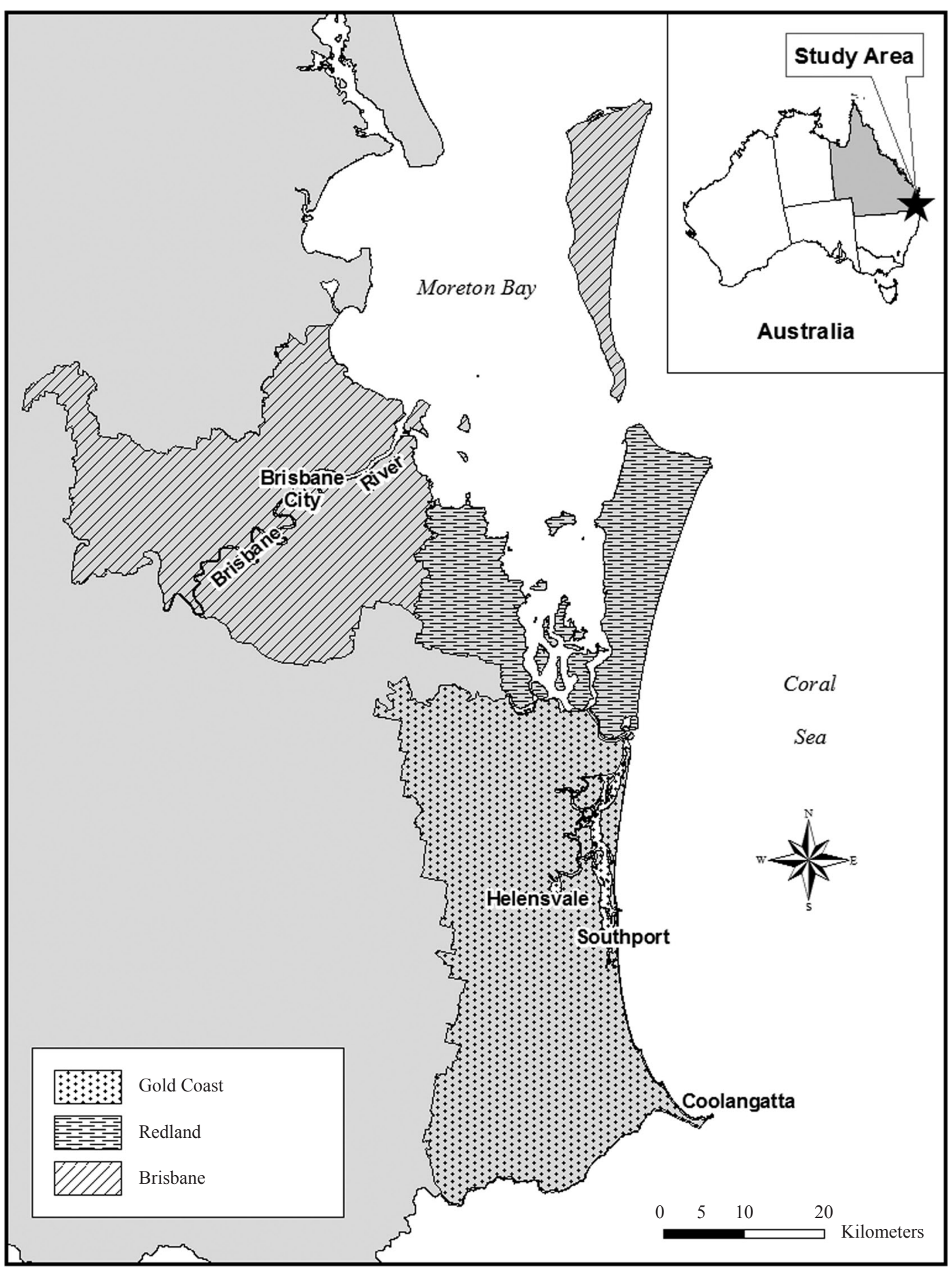

Figure 1. Three local government authorities in South East Queensland (produced by C Qi Li, 2012).

for Sustainability (formerly the International Council for Local Environmental Initiatives) (Betsill and Bulkeley, 2006; Bulkeley, 2000b; Gupta, 2010; Zahran et al, 2008).

The Australian Federal Government has recently introduced a highly controversial 'carbon tax' as a step towards a national emissions trading scheme, similar to that operating in the European Union. This is the centrepiece of a broader strategy that has largely rested on technical analyses of the relations between the environmental effects of climate change and the economic impacts of managing them: in particular, impact modelling, risk assessment, 
and cost-benefit analysis (Howes et al, 2010). This approach reproduces what Byrne et al (2009) and Curran (2011) have characterised as a 'weak' ecological modernisation agenda. Proponents of ecological modernisation assert that environmental problems can be decoupled from economic growth by restructuring the state, industry, and the market to make these institutions operate more efficiently, employing scientific processes and knowledges to do so (Blowers, 1997; Christoff, 1996; Keil and Desfor, 2003; Mol and Sonnenfeld, 2000; Welford and Hills, 2004). They suggest that environmental problems can be 'solved' without sacrificing growth; indeed, they can be recast as economic 'opportunities' (Annandale et al, 2004; Crowley, 1999; Hobson, 2006). And, in fact, some of the most pervasive strategies used at the national and state levels involve targeted intensification of urban development, subsidising the development of 'green' technologies, and providing financial incentives to industry and householders to use them (see Byrne et al, 2009; Curran, 2011; Howes et al, 2010).

In SEQ three transscalar influences stand out as particularly important for local government climate policy: the international network ICLEI-Local Governments for Sustainability; the Commonwealth's Local Adaptation Pathways Program (LAPP); and a suite of policies and programmes under the State of Queensland's ClimateQ strategy. The first of these provides a range of information, training, and support services, including toolkits and 'ready-made' policy instruments such as triple-bottom-line reporting templates, to help local governments 'bridge science and practice' under its Sustainable Cities, Cities for Climate Protection (CCP), and Resilient Cities programmes, among others. All three of the cities discussed in this paper are, or have been, members of ICLEI's CCP.

The LAPP provides funding for local climate change risk assessments and action plans, and was the financial source for much of the underlying research for both Gold Coast's and Redland's strategies. The funding comes with guidance as to how the research should be undertaken, which potentially shapes the response rather tightly. One of the emphases in the guidelines is on communication and consultation; the definition of who should be consulted is worth quoting in full:

"Reasons to include someone in the team may be that he/she:

- is a source of relevant information about the organisation's susceptibility to climate change, providing climate change expertise or an understanding of how the organisation's activities will be affected by climate change;

- is the organisational owner of important functions or assets;

- has the authority to act on or sanction action on treatment requirements; and

- is required to ensure that the process itself proceeds smoothly with personnel and other resources being made available as required to participate in the process and manage the administration of the exercise" (Broadleaf Capital International and Marsden Jacob, 2006, page 20).

The implication here is clear: climate change adaptation planning is founded on information, institutional authority, and material resources. While we agree that these are crucial, the absence of social and cultural values, or recognition of implications for social inclusion, is nonetheless startling.

The state strategy ClimateQ: Toward a Greener Queensland (Queensland Government, 2009a) provides strategic programmes and guidance for state, regional, and local climate change responses. Assistance for local government under this strategy includes funding for disaster preparedness and low-emission energy generation; various information and analysis tools; and guidelines for infrastructure and urban planning. In relation to planning at the regional level, ClimateQ (page 122) promises a South East Queensland Climate Change Management Plan. A draft of this plan (Queensland Government, 2009b) was prepared in 2009 
under the Integrated Planning Act 2003 (since superseded by the Sustainable Planning Act 2009 ) to implement the climate change policies of the South East Queensland Regional Plan (Queensland Government, 2009c); its finalisation is currently on hold pending the outcomes of its public comment process and of a Commission of Inquiry into the devastating SEQ floods in early 2011. The (now dismantled) State Office of Climate Change also released a climate change adaptation issues paper (Queensland Government, 2011), strongly emphasising the need for "science and policy integration" (page 6), continuing the technocratic flavour of the earlier documents. ${ }^{(4)}$

These strategies and programmes set the scene for local actions in SEQ. A key concern for our purposes, though, is that they also establish some fundamental framing positions, potentially leaving little space for local specificities. These include, in particular:

- an assumption that population growth and urban expansion are inevitable - and desirable - in SEQ;

- unquestioning acceptance of projections, targets, directions, and instruments received from the Commonwealth, with little reference to any alternative sources of knowledge about the nature of the changes and the expected impacts;

- a reductionist approach to environmental management, not only 'containing' regions and localities within jurisdictional boundaries but also breaking the response into discrete elements with no explicit reference to their interconnectedness;

- an extremely top-down relationship between government and an apparently homogeneous 'community', whose role is limited to 'behaviour change' and having their awareness increased;

- little or no acknowledgement of the uneven impacts of climate change or policy responses on marginalised and vulnerable people.

To better understand how this framing plays out on the ground, we now turn to interrogate the three policies focused at the municipal scale.

\section{Local government action plans interrogated}

The analysis described below focuses closely on three specific documents-local government action plans published between 2007 and 2010 for the management of climate change impacts. Each of these texts represents an explicit institutional commitment - at the municipal scaleto a range of strategies and actions by the Cities of Brisbane, Gold Coast, and Redland, respectively (see figure 1).

Table 2 briefly summarises our text analysis according to our analytical questions. As the discussion below elaborates, it indicates that the technocratic tendencies of 'higher' level responses are, indeed, reproduced at the local government level. That is, all three documents show a similarly managerial approach to dealing with the issues raised by climate change, draw exclusively on scientific knowledge and received policy, and construct a top-down relationship between the council and its citizens. Specific or inferred reference to issues of social justice, equity, and inclusion in relation to climate change adaptation were almost entirely absent. How each document realises these features is further detailed below.

(4) One of the first actions of the newly elected Liberal-National (conservative) Queensland state government, under the direction of Premier Campbell Newman, was to dismantle the state's climate change institutional apparatus in 2012, purportedly to reopen the state for development. 
Table 2. Summary of text analysis.

\begin{tabular}{|c|c|c|c|}
\hline Question & Brisbane & Gold Coast & Redland \\
\hline Climate change & local challenge & $\begin{array}{l}\text { global challenge, unique } \\
\text { local impacts; economic } \\
\text { opportunities }\end{array}$ & $\begin{array}{l}\text { scientific consensus; local } \\
\text { risks }\end{array}$ \\
\hline Local people & $\begin{array}{l}\text { abstract community, } \\
\text { requiring education }\end{array}$ & $\begin{array}{l}\text { homogeneous community, } \\
\text { requiring education }\end{array}$ & $\begin{array}{l}\text { homogeneous community, } \\
\text { requiring education }\end{array}$ \\
\hline Relations & council as actors & $\begin{array}{l}\text { council and other } \\
\text { unspecified leaders }\end{array}$ & $\begin{array}{l}\text { government equal across } \\
\text { scales, leading community }\end{array}$ \\
\hline Knowledge & institutional & institutional; scientific & scientific; institutional \\
\hline Agency & council, top down & $\begin{array}{l}\text { council, business, top } \\
\text { down }\end{array}$ & $\begin{array}{l}\text { council, government, top } \\
\text { down }\end{array}$ \\
\hline Intertexts & $\begin{array}{l}\text { a internal, government } \\
\text { programmes } \\
{ }^{b} \text { institutional }\end{array}$ & $\begin{array}{l}\text { a internal, government } \\
\text { programmes, government- } \\
\text { generated science } \\
{ }^{\mathrm{b}} \text { institutional, promotional, } \\
\text { technical }\end{array}$ & $\begin{array}{l}\text { a internal, government } \\
\text { programmes, government- } \\
\text { generated and peer- } \\
\text { reviewed science } \\
\text { b educational, scientific, } \\
\text { institutional, technical }\end{array}$ \\
\hline
\end{tabular}

\section{Brisbane's "Plan for Action"}

"Brisbane's Plan for Action on climate change and energy" (Brisbane City Council, 2007) compiles a selection ${ }^{(5)}$ of recommendations from the final report of Council's Climate Change and Energy Taskforce (Maunsell Australia, 2007). It was adopted by the council in April 2007 and released for public comment for the month of June 2007, but no amendments seem to have been made after that. It uses minimal graphic devices, apart from a green banner and cover photo, and takes the form of a list of proposed actions to be undertaken by the council. These actions are framed through three key discursive strategies: an introduction briefly explaining climate change as a set of generic "challenges for Brisbane" (Brisbane City Council, 2007, page 1); background chapters outlining the document's own history and referring the reader to the Taskforce report for further context; and eight chapter headings classifying the actions.

The first three classifying chapter headings are: "Leadership and partnering"; "Decision making"; and "Communication and education". ${ }^{(6)}$ That these dimensions of council action are thematised in this way suggests a focus on governance, normally considered a key area for the inclusion of marginalised people and acknowledgement of difference (Abram, 2000; Abu-Lughod, 1998; Gould, 1996; Sandercock, 1998; Young, 2000). However, there is little evidence of either here. Indeed, the Taskforce's only recommendation to specifically mention "consideration of vulnerable communities", the establishment of heatwave/heat stress response plans (Maunsell Australia, 2007, page 46) was not included in the adopted plan.

${ }^{(5)}$ The Taskforce report made 31 recommendations with 156 specified implementation actions; the adopted recommendations number 25 with 96 specified actions. Apart from the development of a heatwave/heat stress response plan, discussed below, the actions not adopted - due to a lack of consensus at the council- tended to fall into four categories: emission reduction targets beyond those already adopted as part of the Brisbane 2026 Vision (Brisbane City Council, 2006); budget allocations; imposition of fees and charges; and collaborations with state government agencies.

${ }^{(6)}$ The others are: "Strategic and land use planning"; "Sustainable transport"; "Preparedness for change, emergencies and surprises"; "Diversification and conservation of natural resources"; and "Research". 
References to external parties are limited to institutionalised policy networks (eg, Australian 'Greenhouse Office's' (AGO) 'Greenhouse Friendly' certification, page 5), the state, and the Commonwealth government. Local people are generally subordinated to functional categories: 'homes/residences', 'commercial premises/businesses/employers'. 'Community' consistently appears embedded in abstract nominal groups such as 'community education', 'community awareness', 'community attitudes' - that is, it is presented as an abstract entity whose main role in implementing the plan is to be educated.

In spite of the fact that education is said to be important to "ensuring community involvement in the ongoing development of responses" (Brisbane City Council, 2007, page 9), actions under the "Communication and education" heading are exclusively top down: a "communication and branding program" whose elements include "awareness and attitudinal targets [sic] for residents", "consistency of messages", and maximised "value of communication" (page 9); and "community-based social marketing efforts designed to achieve specific behaviour changes" (page 9). In sum, the document construes communication and education as tools, intended explicitly to minimise difference in attitudes, knowledge, and behaviour. The 'community' (and any alternative descriptions of people living in Brisbane) are absent from other chapters, including that on decision making.

In other ways, too, Brisbane's plan presents a top-down approach to climate change adaptation. It draws variously on technical policy discourses, occasionally using unexplained acronyms (eg, AGO, ASBEC, page 5) or institutional references (eg Q100, page 11; Australia Trade Coast, page 13). Although the council is construed as a conscious agent whose actions have real effects, with many recommendations taking the form "Council will ... to achieve ..." or "Council should ...", it is an agent with no personal identity: evaluative statements are limited to what Iedema and Grant (2004) call 'normative moralisation' - appraisal markers which express identity and orientation in institutional or functional terms (eg, 'effective' rather than 'good'; a 'strong' relationship rather than a 'friendly' or 'happy' one). The document also makes heavy use of grammatical nominalisation to reduce diffuse relations and processes to manageable, or creatable, 'things' (eg, 'partnership', 'relocation', 'incentives', 'robust approaches'). ${ }^{(7)}$ Indeed, the classification of actions is itself a reductionist strategy, creating manageability by construing aspects of the strategy as discrete and independent, and relationships between various phenomena (including especially actions and outcomes) as simply causal rather than complex (cf Hajer, 1995; 2003).

Such strategies can be seen as discursive hallmarks of the ecological modernisation paradigm - the construction of manageability leads directly to acceptance of technical and institutional solutions as the only way forward and, concomitantly (in the strong versions of ecological modernisation), imagines economic opportunities to develop and market the required technologies (one of the explicit aims of this strategy, page 1). The flip side to this is, of course, that solutions are accessible to most actors at the neighbourhood and household scales in only their role as consumers - obedient consumers, in this case, as we have seen (cf Hobson, 2006).

\section{Gold Coast's "Climate Change Strategy"}

The Gold Coast City Council's "Climate Change Strategy 2009-2014" (2009a) is the latest in a series of climate documents published under the aegis of ICLEI's CCP, and was produced internally with LAPP funding. It was released, with considerable fanfare, as "Australia's most comprehensive local plan to address, and respond to, climate change" (Fineran, 2009), and presents a slick, glossy face with full-colour printing, multiple graphics, and photographs on almost every page. While the 2009 strategy differs from earlier ones (Gold Coast City Council, 2001; 2007) in its specific focus on adaptation as well as mitigation measures,

(7) 'Climate change' and 'sustainability' are, of course, themselves supreme examples of this. 
it gives similar emphasis, in line with the ecological modernisation tradition, to treating climate change as an 'opportunity' as well as a challenge. The Council's Sustainable City Future Committee Chairman, Peter Young, was quoted about the need to urgently adopt the plan: "There are ... significant financial benefits for us in the short, mid and long term, and we need to start sooner rather than later" (Fineran, 2009). The photographs chosen for the report support this vision, featuring production processes, beautiful landscapes, and smiling children, rather than the more alarming images of stormy weather, fire, and coastal erosion that characterise many climate change plans, including this one's immediate predecessor (Gold Coast City Council, 2007).

Following a very brief executive summary, which frames the city's exposure to climate change as "particularly unique" (Gold Coast City Council, 2009a, page 1), the strategy begins with a background chapter that overviews climate change and frames the Council's response against the backdrop of its broader "Bold Future" strategy (Gold Coast City Council, 2009b), noting an increasing sense of urgency about the issue since 2007 (Gold Coast City Council, 2009a, page 4). The next three chapters comprise the strategy proper: chapter 3 outlines the vision, objective, and outcomes; chapter 4 discusses performance measures and reporting; and chapter 5 identifies how the strategy is to be implemented. Three technical appendices present the LAPP-funded action plan (including many interventions that had been planned for some years prior), risk assessment, and carbon footprint analysis on which the strategy is predicated.

The tone of the document is established in the first section, with elided agency achieved through use of the passive voice and nominalisations; for instance: "It is anticipated that climate change will impact Gold Coast weather patterns and amplify the occurrence of extreme events like cyclones and heat waves" (Gold Coast City Council, 2009a, page 1). This latter strategy also enables complex processes to be represented as causal and other relations between reified phenomena (climate change-weather patterns-extreme events), a key characteristic of the scientific discourse through which our broader understanding of climate change is mediated (Halliday and Martin, 1993). These internationally circulating discourses, realised in specific texts such as the IPCC (2007) Assessment Report and various Australian applications (eg, Abbs et al, 2007; CSIRO, 2007; CSIRO and BOM, 2007; OCC, 2008), are explicitly acknowledged in chapter 2 as the knowledge base for the strategy, and the monitoring and review arrangements are explicitly linked to the need to reflect developments in climate science and technology (Gold Coast City Council, 2009a, pages 11 and 16). The scientistic nature of the document is further reinforced in its tabular presentation of the outcomes and performance measures (all expressed as 'percentages') in chapter 4, and in the technical appendices. Mention of local experiential knowledge or community involvement is limited to the following statement (in full): "At various stages in the lifecycle of strategy development, stakeholders, service owners and Council's Executive Leadership Team were invited to provide comment" (page 4).

Although the executive summary states that "Council envisages that the city's leaders and the community will work in partnership to achieve climate change resilience for our future" (Gold Coast City Council, 2009a, page 1), the remaining document spells out a relationship that is more paternalism than 'partnership'. Grammatically, the council consistently acts upon others - they will "lead the community" (page 1), and "prepare the city and the community to be climate change resilient" (page 3), for example - and $40 \%$ of the proposed actions (13/35) fall under the first of seven aspirational 'strategic outcomes': "Council is a leader in localised action ..." (page 11). Other community-related actions, like Brisbane's, are oriented exclusively to education and training: "improved awareness and understanding", here (page 13). Also, like Brisbane's plan, there is no mention of social diversity at all, and 
the possibility of unevenly distributed impacts is relegated to the appended risk assessment, with "low income groups" embedded in one of six points under the high-priority risk "social sustainability" (page 27). None of the associated actions specifically targets low-income groups, however.

\section{Redland's "Confronting our climate future"}

Redland's "Confronting our climate future" (2010a) is the most recent of the three strategies, having been published in August 2010 with a promise to review after a public comment period of six months; it replaces the City's "Local Greenhouse Action Plan" (Redland Shire Council, 2003) and the draft Redlands "Climate Change Risk Assessment and Adaptation Plan" (Marsden Jacobs and Broadleaf Capital International, 2009). Like the Gold Coast's, the research and development of the strategy underlying was largely funded by the LAPP (and, in this case, undertaken by the consultants who wrote the Commonwealth guidelines) - though both cities are longstanding members of CCP, their principal source of material support has shifted from the international network to the national programme. Redland's is the most substantial of the three strategies in both content and presentation; though far less glossy than that of the Gold Coast, it provides a more detailed, self-contained, and textually structured argument, and is clearly written for a general readership.

The first chapter thematises the scientific consensus on climate change to justify the need for action. Unlike the others, though, Redland's places the strategy in a framework of government responsibilities and initiatives. It also introduces a threefold distinction which structures the local analysis in the expository Part 1 of the document: mitigation, adaptation, and energy transition. This local analysis is focused on risks and impacts of climate change, to 'the Redland community' and 'council' (as a corporate entity) in separate chapters. Part 2 presents corporate policy, 'strategic outcomes', and a detailed five-year action plan, in which the mitigation/adaptation/transition distinction is sustained only implicitly, though that between corporate and community actors remains explicit, as does the focus on risk. The reductionist approach to management is evident here, as in the other two strategies.

The Redland strategy identifies itself as a response to a "community vision for "green living"' (Redland City Council, 2010a, page 9), an outcome of their engagement process for the more general "2030 Community Plan" (Redland City Council, 2010b). Yet this document constructs the relationship of the Council to 'the community', like that of the other councils, as leadership, in explicit contrast with their 'partnership' relation with other levels of government (Redland City Council, 2010a, page 27). Similarly, 'community' is consistently presented as unproblematic and homogeneous, though in the action plan and appended risk assessment, for some reason, the risk of "anxiety about climate change" is associated particularly with the elderly (pages 38 and 52). This deeply subordinated association is the document's sole acknowledgement of difference. This is in spite of explicit acknowledgment of 'social disruption' as a generic risk of climate change impacts (page 20). And, although the expected awareness-raising actions have been expanded to include "communication, engagement and action" plans across a range of themes (page 46), no definition or detail is provided as to what this 'engagement' might look like. Indeed, the aims of these plans are consistently oriented to education and behaviour change around generic, rather than locally specific, responses to climate change and energy use. Indeed, the Redland document is barely concerned with local specificities even in the environmental and economic dimensions - certainly less than either of the other documents. ${ }^{(8)}$

Also, like the other documents, there is no specific mention of local people as sources of knowledge or direction for the development of the strategies. Rather, the text draws on scientific and government sources to legitimise its claims, referring the reader to specific

${ }^{(8)}$ This may be because the underlying research was undertaken by consultants instead of internally. 
policy and research publications in highlighted boxes such as "Follow government initiatives" (Redland City Council, 2010a, page 14); "Follow the science" (page 18); and "Reading about the risks" (page 20). It shifts from a generally educational register (discursive, readerfriendly, and illustrated with inspirational cartoons) to a highly technical one (tabulated, jargonistic) between parts 1 and 2, but sustains throughout a scientistic, detached orientation to agency, cause-effect relations, and judgment through the usual strategies of passive voice, nominalisation, and performative appraisal.

\section{Framing climate change discourses}

In sum, although there are differences between the strategies-in particular, Brisbane's appears to be written essentially for internal consumption, Gold Coast's for promotion, and Redland's for education-all three realise a generic technocratic management approach to both understanding and responding to the problems posed by climate change, redolent of the 'weak' ecological modernisation agenda pervasive at higher levels of Australian climate policy. Councils are positioned in a dominant relationship with their people, facilitating transfer of global science and national/state policy discourse into the local contexts, with attention to only the physical environmental, administrative, and economic dimensions of those contexts and not to social differences or inequities. While leadership on the part of a council is surely no bad thing, in these documents it takes a problematic form which tends to deny agency to an undifferentiated 'community'. None of the strategies creates any space of possibility for dialogue between different ways of knowing or acting, preferring rather to educate their citizens in the accepted science and now normative technologies of adaptation, with a view to changing local understandings and behaviours in response to that 'superior' knowledge.

This may come as no surprise. The fact that local action is enabled largely by intellectual and material support from international networks and higher levels of government suggests that its content, structure, and style are likely to be heavily shaped by these transscalar influences. However, these findings are also disappointing. They seem to us to represent a missed opportunity both to engage with local people's experiences, understandings, and desires in relation to this most important of issues, and to embed social inclusion and justice considerations in public responses to the potentially immense environmental and economic changes that we know are coming. As such, there is a risk that they will fail to appear directly relevant or to gain traction with much of the local citizenry. More troubling still, each reinforces a dominant discursive and material framing which brackets justice and equity considerations as tangential to the 'serious' environmental and economic problem (see also MacCallum et al, 2011).

Moreover, these findings suggest some serious tensions with broader governance objectives expressed by the State of Queensland and the councils themselves, all of which publically celebrate social diversity, social inclusion, and community consultation. The SEQ Regional Plan specifically requires "engaged governance - ensuring broad community involvement in decisions and actions that affect people" (Queensland Government, 2009c, page 39) also that "Aboriginal and Torres Strait Islander peoples are actively involved in community planning and decision-making processes, and Aboriginal traditional owners are engaged in business about their country" (page 84 ). The City of Brisbane's community engagement policy promises engagement that supports social inclusion and, more specifically, addressed "obstacles to participation" by maximising participation opportunities for marginalised people (Brisbane City Council, nd, page 3). Redland's is equally strong, including undertaking to "target the ways in which we engage with the community to acknowledge community diversity" (Redland City Council, 2010c, page 2). 
Yet there is little evidence to suggest that any of this has occurred - or will occurin association with the state or local authority climate change strategies. Climate change response is surely a policy area in which decisions must have major repercussions on both citizens (cf 'behaviour change') and the management of country - otherwise, they are highly unlikely to be effective (Dankelman, 2002; Davies, 2001; Few et al, 2007). How, then, has the 'inclusion ethic' become so thoroughly set aside? We see the similarities between these documents as evidence that discourse on climate change could be constrained at the municipal level by the technical 'masterframes' (Eder, 1996) of weak ecological modernisation which circulate globally and which appear to dominate policy at higher levels of government (Curran, 2011; Rutland and Aylett, 2008; Zahran et al, 2008). One of the outcomes of this dominance appears to be the segregation of climate change and social inclusion discourses (MacCallum et al, 2011) and, concomitantly, a lack of attention within climate change responses to the social factors which produce and unevenly configure vulnerability (Ikeme, 2003) — a 'gentrification' of climate change which smooths over uneven contextual vulnerabilities in favour of economic opportunity (Glasson, 2012).

Discursive exclusion is a form of social exclusion, with material as well as cultural consequences (Fairclough, 1989; Jessop and Oosterlynck, 2008; Sum, 2011); conversely, by giving local specificity and difference a place - both procedurally and discursively - in policy making, local governments can create new possibilities for inclusion. In the face of major environmental and economic changes, in which the socio-economically vulnerable are traditionally hit hard (Nicholson 2007), we should not ignore these possibilities.

\section{Climate justice and local governance}

Barnett (2006, page 115) compellingly argues that "climate change policies may themselves create unfair outcomes by exacerbating, maintaining or ignoring existing and/or future inequalities." Yet the urgency surrounding climate change as a global issue, and the nature of the support available, seems to force some local governments to acts - at least on paperwithout due attention to such inequalities (Wilson et al, 2010). The unreflective adoption of technocratic discourses allows climate change impacts to be construed as undifferentiated across the jurisdiction, and policy costs and benefits to be consequently presented as equally distributed. We know that neither is a 'true' representation of reality: while most of the discourse on climate (in)justice is focused on the global scale (eg, Angus, 2009; Goodman, 2009; Liverman, 2009; Walker, 2009), uneven vulnerabilities are also evident at the national, urban, and local scales (Adger et al, 2006; Brotherhood of St Laurence, 2007; Edwards et al, 2009; Gasper et al, 2011). Therefore, alternative discourses on climate change are urgently required: discourses which can engage diverse local publics in agenda setting and attend reflexively to their own social and cultural effects.

While funding conditions and National/State directives do represent real constraints on local climate policy, they do not, in themselves, prevent local authorities from attending to local differences or from engaging with their citizens in defining the response. As climate change activists have long recognised, local achievements can have larger-scale influences, particularly when they become part of the popular discourse. How exciting it could be to reimagine the current environment of uncertainty not as a lack requiring the artificial construction of ecological-modernisation-style manageability, but instead as a space of creative potential, as an opportunity to open the dialogue to new voices and to embed a local/ regional-scaled ideal of climate justice in our language and action (Evans, 2008; Fritze and Wiseman, 2009; Wilson et al, 2010).

To this end, we tentatively propose some characteristics that such an ideal might embody in practice. The strategies listed below draw on a range of theoretical and praxis-oriented sources, guided by some overarching principles which have recently been elaborated under 
the framework designation, "climate-just city" (Steele et al, 2012). This framework rethinks Susan Fainstein's (2000; 2010; Marcuse et al, 2009) 'just city', founded on democracy, social diversity, difference and equity, in relation to the climate change crisis. To tease this out a bit, we believe that local responses to climate change could:

- Acknowledge the incompleteness of scientific and statistical data as a collective reality. We accept the weight of scientific evidence that shapes the imperative to act on climate change, but we also accept that this evidence - and the way that it is presented in reports and policy - cannot hope to resonate with the understanding of all citizens. People imagine, experience, and practise climate change and social justice in many ways; policy process needs to be open to a variety of genres, discourses, and registers through which such 'evidence' can be expressed (Demerrit, 2001; Evans, 2008, Gibson et al, 2010).

- Explicitly consider multiple axes of difference-including (but not limited to) class, race, ethnicity, gender, family structure, age, lifestyle, housing tenure - and the ways that these configure the differential impacts of climate change and climate change policy (Congressional Black Caucus Foundation, 2004; Denton, 2002; Nelson et al, 2002; Nyong et al, 2007).

- Attend to the spatial distribution of actual and potential climate change impacts - not merely in relation to sea-level rise and exposure to storm events (Department of Climate Change, 2009; de Vries, 2006) but also in terms of vulnerability to heat stress, insect-borne diseases, and economic marginalisation (Baum et al, 2009; Byrne, 2008; Evans, 2008; Kelly and Adger, 2000).

- Establish (materially supported) relationships with institutions, organisations, partnerships, and other assets that provide resources for traditionally marginalised communities to meet their basic, social, cultural, and political needs (Kretzmann and McKnight, 1993; Mathie and Cunningham, 2003; Moss, 2009; Pelling et al, 2008).

- Create formal and informal spaces in which the voices of a differentiated public can be heard (Bell, 2010; Fincher and Iveson, 2008; Young, 1990; 2000).

- Recognise the social and alternative economies as they operate regionally and locally, not just the business economy (Gibson-Graham, 2008; Gibson-Graham and Roelvink, 2009; Moulaert et al, 2005).

The above points are not, of course, intended to be comprehensive; this would be quite contrary to the spirit of inclusive and locally specific dialogue that we wish to promote. Nor are they supposed to represent a universal approach to solving a complex and more-thanlocal problem. Rather, they are a small contribution to an ongoing project which we hope will embrace many more people in its evolution.

\section{Concluding remarks}

Climate change is now a mainstream and highly active policy issue at every level of Australian government. While there remains conflict over many substantive details of the policies, including the explanatory storylines about climate change as a phenomenon (see Bulkeley, 2000a; Fisher, 2012; Hajer, 1995), there is a surprising lack of variety in relation to the broader framing of the problem as a technical environmental and economic one, whose social implications are largely treated as tangential to the main game. With this paper we analyse three local government strategies to demonstrate that this is the case even at the municipal level of government in SEQ, where local specificity and political inclusion are often at the forefront of public discourse surrounding policy practice. We suggest that the convergence is at least partly attributable to discursive framings received - along with material and intellectual support - from governance networks that operate at larger scales (Betsill and Bulkeley, 2006). We believe that this places profound limitations on municipalities' capacity to enact a socially inclusive response to climate change. Further research should explore local 
policy processes for spaces in which alternative framings - including locally specific forms of knowledge and agency — might be acknowledged and, if appropriate, put to work to help overcome those limitations.

Acknowledgements. We thank the editors of Environment and Planning $C$ and the two anonymous referees for their very helpful comments on this paper.

\section{References}

Abbs D, McInnes K, Rafter T, 2007 The Impact of Climate Change on Extreme Rainfall and Coastal Sea Levels over South-East Queensland (CSIRO, Aspendale, Victoria)

Abram S, 2000, "Planning the public: some comments on empirical problems for planning theory" Journal of Planning Education and Research 19 351-357

Abu-Lughod J, 1998, "Civil/uncivil society: confusing form with content", in Cities for Citizens: Planning and the Rise of Civil Society in a Global Age Eds M Douglass, J Friedmann (John Wiley, New York) pp 227-238

Adger J, Paavola S, Huq M, Mace M (Eds) 2006 Fairness to Adaptation to Climate Change (MIT Press, Cambridge, MA)

Amundsen H, Frode B, Westskok H, 2010, "Overcoming barriers to climate change adaptation-a question of multilevel governance?" Environment and Planning C: Government and Policy $\mathbf{2 8}$ 276-289

Angus I (Ed.), 2009 The Global Fight for Climate Justice (Resistance Books, London)

Annandale D, Morrison-Saunders A, Duxbury L, 2004, "Regional sustainability initiatives: the growth of green jobs in Australia" Local Environment 9 81-87

Aylett A, 2010, "Participatory planning, justice, and climate change in Durban, South Africa" Environment and Planning A 42 99-115

Bailey I, Wilson G, 2009, "Theorising transitional pathways in response to climate change: technocentrism, ecocentrism, and the carbon economy" Environment and Planning $A$ $412324-2341$

Bakhtin M M, 1981 The Dialogic Imagination: Four Essays (University of Texas Press, Austin, TX)

Barnett J, 2003, "Security and climate change" Global Environmental Change 13 7-17

Barnett J, 2006, "Climate change, insecurity and injustice", in Fairness to Adaptation to Climate Change Eds W Adger, J Paavola, S Huq, M Mace (MIT Press, Cambridge, MA)

Baum S, Horton S, Low Choy D, Gleeson B, 2009, "Climate change, health impacts and urban adaptability: case study of Gold Coast City”, Research Monograph 11, Urban Research Program, Griffith University, Brisbane

Bell, D, 2010, "Ethics, justice and climate change" Environmental Politics 19 475-479

Betsill M, Bulkeley H, 2006, "Cities and the multilevel governance of global climate change" Global Governance 12 141-159

Blowers A, 1997, “Environmental policy: ecological modernisation or risk society?" Urban Studies $34845-871$

Brisbane City Council

2006 Our Shared Vision: Living in Brisbane 2026 http://www.brisbane.qld.gov.au/about-council/council-vision-strategies/living-in-brisbane-2026/ living-in-brisbane-2026-vision-documents/index.htm

2007, "Brisbane's Plan for Action on climate change and energy" http://www.brisbane.qld.gov.au/2010\%20Library/2009\%20PDF\%20and\%20Docs/1.About\%20 Council/1.6\%20Council\%20vision\%20and\%20strategies/councilvision_and_strategies_ planforactiononclimatechange.pdf

nd, "Brisbane city council community engagement policy", http://www.brisbane.qld.gov.au/prdc/groups/corpwebcontent/documents/documents/038565.pdf

Broadleaf Capital International and Marsden Jacob, 2006 Climate Change Impacts and Risk Management: A Guide for Business and Government Australian Greenhouse Office, Canberra

Brotherhood of St Laurence, 2007, "Equity in response to climate change roundtable report", copy available from Brotherhood of St Laurence, 67 Brunswick Street, Fitzroy, Vic 3065

Bulkeley H, 2000a, "Discourse coalitions and the Australian climate change policy network" Environment and Planning C: Government and Policy 18 727-748 
Bulkeley H, 2000b, "Common knowledge? Public understanding of climate change in Newcastle, Australia" Public Understanding of Science 9 313-333

Bulkeley H, Betsill M, 2003 Cities and Climate Change: Urban Sustainability and Global Environmental Governance (Routledge, London)

Buys L, Miller E, van Megan K, 2012, "Conceptualising climate change in rural Australia: community perceptions, attitudes and (in)actions" Regional Environmental Change 12 237-248

Byrne J, 2008, "Equity mapping", in Positive Development: From Vicious Circles to Virtuous Cycles Through Built Environment Design Ed. J Birkeland (Earthscan, London) page 336

Byrne J, Gleeson B, Howes M, Steele W, 2009, "Climate change and Australian urban resilience: the limits of ecological modernization as an adaptive strategy", in Planning for Climate Change: Strategies for Mitigation and Adaptation for Spatial Planners Eds S Davoudi, J Crawford, A Mehmood (Earthscan, London) pp 136-154

Campbell D, Stafford Smith M, Davies J, Kuipers P, Wakerman J, McGregor M, 2008, "Responding to health impacts of climate change in the Australian desert" Rural and Remote Health 8 1-9

Capetola T, 2008, "Climate change and social inclusion: opportunities for justice and empowerment" Just Policy 47 23-29

Chouliaraki L, Fairclough N, 1999 Discourse in Late Modernity: Rethinking Critical Discourse Analysis (Edinburgh University Press, Edinburgh)

Christoff P, 1996, "Ecological modernisation, ecological modernities" Environmental Politics $5476-500$

Collins C, 1999, “Applying Bakhtin in urban studies: the failure of community participation in the Ferguslie Park Partnership" Urban Studies 36 73-90

Commonwealth of Australia, 2012a, "Social Inclusion", http://www.socialinclusion.gov.au/

Commonwealth of Australia, 2012b Social Inclusion in Australia: How Australia is Faring 2nd edition (Australian Social Inclusion Board, Canberra)

Congressional Black Caucus Foundation, 2004 African Americans and Climate Change: An Unequal Burden Available from Congressional Black Caucus Foundation, Inc., Washington, DC

Conner T, 2008 "Social vulnerability and adaptive capacity to climate change impacts: identifying attributes in two remote coastal communities on Haida Gwaii, British Columbia" MA dissertation, Department of Geography, University of Victoria, BC, Canada

Crick F, Serrao-Neumann S, Low-Choy D, Baum S, 2012, "A region at risk: policy determination through vulnerability hotspot assessment", in Resilient Cities 2, Local Sustainability

Ed. K Otto-Zimmermann, (Springer, Dordrecht) pp 15-24

Crowley K, 1999, "Jobs and environment: the 'double dividend' of ecological modernisation?" Economics 26 1013-1026

CSIRO, 2007, "The impact of climate change on extreme rainfall and coastal sea levels over South East Queensland", CSIRO, Canberra

CSIRO, BOM, 2007, "Climate change in Australia, Technical Report", CSIRO, Canberra

Curran G, 2011, "Modernising climate policy in Australia: climate narratives and the undoing of a Prime Minister" Environment and Planning C: Government and Policy 29 1004-1017

Dankelman I, 2002, "Climate change: learning from gender analysis and women's experiences of organising for sustainable development" Gender Development 10 21-29

Davies A, 2001, "What silence knows: planning, public participation and environmental values" Environmental Values $1077-102$

Demeritt D 2001, "The construction of global warming and the politics of science" Annals of the Association of American Geographers 91 307-337

Demetriades J, Esplen E, 2008, "The gender dimensions of poverty and climate change adaptation" IDS Bulletin 39 24-31

Denton F, 2002, "Climate change vulnerability, impacts, and adaptation: why does gender matter?" Gender Development 10 10-20

Department of Climate Change, 2009 Climate Change Risks to Australia's Coast Commonwealth Government, Canberra

de Vries J, 2006, “Climate change and spatial planning below sea-level: water, water and more water" Planning Theory and Practice 7 223-227 
Dodson J, Sipe N, 2008a, "Shocking the suburbs: urban location, homeownership and oil vulnerability in the Australian city" Housing Studies 23 377-401

Dodson J, Sipe N, 2008b ,"Unsettling suburbia: the new landscape of oil and mortgage vulnerability in Australian cities", RP 17, Urban Research Program, Griffith University, Brisbane, http://www.griffith.edu.au/_data/assets/pdf_file/0003/88851/urp-rp17-dodson-sipe-2008.pdf

Eder K, 1996 The Social Construction of Nature: A Sociology of Ecological Enlightenment (Sage, London)

Edwards T, Fritze J, Wiseman J, 2009, "Community well-being in a changing climate: challenges for the Australian community sector" Just Policy $\mathbf{5 0} 80-86$

Evans G R, 2008, “Transformation from 'carbon valley' to a 'post-carbon society' in a climate change hotspot: the coalfields of the Hunter Valley, New South Wales, Australia" Ecology and Society 13 39-59

Fainstein S, 2000, "New directions in planning theory" Urban Affairs Review 35 451-478

Fainstein S, 2010 The Just City (Cornell University Press, Ithaca, NY)

Fairclough N, 1989 Language and Power (Longman, London)

Fairclough N, 1995 Critical Discourse Analysis: The Critical Study of Language (Longman, London)

Fairclough N, 2003 Analysing Discourse: Text Analysis for Social Research (Routledge, London)

Fairclough N, 2005, "Critical discourse analysis in transdisciplinary research", in A New Agenda in (Critical) Discourse Analysis Eds R Wodak, R P Chilton (Benjamins, Amsterdam) pp 53-70

Few R, Brown K, Tompkins E, 2007, "Public participation and climate change adaptation: avoiding the illusion of inclusion" Climate Policy 7 46-59

Fincher R, Iveson K, 2008 Planning and Diversity in the City: Redistribution, Recognition and Encounter (Palgrave Macmillan, New York)

Fineran L, 2009, "City to discuss green strategy", Internet newspage, Gold Coast online news, 6 May, http://www.goldcoast.com.au/article/2009/05/06/76245_gold-coast-top-story.html

Fisher S, 2012, "Policy storylines in Indian climate politics: opening new political spaces?" Environment and Planning C: Government and Policy 30 109-127

Ford J, Smit B, Wandel J, Allurut M, Shappa K, Ittusarjuat H, Qrunnut K, 2008, "Climate change in the Arctic: current and future vulnerability in two Inuit communities in Canada" Geographical Journal 174 45-62

Fritze J, Wiseman J, 2009, "Climate justice: key debates, goals and strategies", in Climate Change and Social Justice Ed. J Moss (Melbourne University Press, Melbourne) pp 187-211

Furgal C, Seguin J, 2006, "Climate change, health, and vulnerability in Canadian Northern Aboriginal communities" Environmental Health Perspectives 12 1964-1970

Garnaut R, 2008 The Garnaut Climate Change Review (Cambridge University Press, Cambridge)

Gasper R, Blohm A, Ruth M, 2011, "Social and economic aspects of climate change on the urban environment" Current Opinion in Environmental Sustainability 3 150-157

Gibson C, Head L, Gill N, Waitt G, 2010, "Climate change and household dynamics: beyond consumption, unbounding sustainability" Transactions of the Institute of British Geographers, New Series 36 3-8

Gibson-Graham J K, 2008, "Diverse economies: performative practices for 'other worlds" " Progress in Human Geography 32 613-632

Gibson-Graham J K, Roelvink G, 2009, "Social innovation for community economies", in Social Innovation and Territorial Development Eds D MacCallum, F Moulaert, J Hillier, S Vicari-Haddock (Ashgate, Aldershot, Hants) pp 25-37

Giorgi F, 2006, "Climate change hot-spots" Geophysical Research Letters 33 L08707

Glasson B, 2012, "Gentrifying climate change: ecological modernisaton and the cultural politics of definition" M/C Journal 15,

http://journal.media-culture.org.au/index.php/mcjournal/article/viewArticle/501

Gold Coast City Council

2001, "The Gold Coast 2010 Cities for Climate Protection Program, 2001 Action Plan" http://www.goldcoast.qld.gov.au/attachment/environment/2010_action_plan.pdf

2007, "Carbon neutral by 2020: Gold Coast City Council responding to climate change", http://www.goldcoast.qld.gov.au/attachment/environment/cc_strategy.pdf 
Gold Coast City Council

2009a, "Climate Change Strategy, 2009-2014", http://www.goldcoast.qld.gov.au/attachment/publications/strategy/climate_change_strategy.pdf 2009b, "Bold Future Vision: 'How we got there ...", http://www.goldcoast.qld.gov.au/attachment/publications/strategy/climate_change_strategy.pdf

Goodman J, 2009, "From global justice to climate justice? Justice ecologism in an era of global warming" New Political Science 31 499-514

Gould C C, 1996, "Diversity and democracy: representing differences", in Democracy and Difference: Contesting the Boundaries of the Political Ed. S Benhabib (Princeton University Press, Princeton, NJ) pp 171-186

Green D, Preston B, 2006, "Climate change impacts on remote indigenous communities in Northern Australia”, RP 012, CSIRO Marine and Atmospheric Research, Aspendale, Victoria 3195, http://sharingknowledge.net.au/files/climateimpacts_health_report.pdf

Green D, Niall S, Morrison J, 2012, "Bridging the gap between theory and practice in climate change vulnerability assessments for remote Indigenous communities in northern Australia" Local Environment: The International Journal of Justice and Sustainability 17 295-315

Gupta J, 2010, "A history of international climate change policy" Wiley Interdisciplinary Reviews: Climate Change 1 635-653

Hajer M A, 1995 The Politics of Environmental Discourse: Ecological Modernization and the Policy Process (Clarendon Press, Oxford)

Hajer M A, 2003, "A frame in the fields: policymaking and the reinvention of politics", in Deliberative Policy Analysis: Understanding Governance in the Network Society Eds M Hajer, H Wagenaar (Cambridge University Press, Cambridge) pp 88-110

Halliday M, 1978 Language as Social Semiotic: The social Interpretation of Language and Meaning (Edward Arnold, London)

Halliday M, 1985 An Introduction to Functional Grammar (Arnold, Sydney)

Halliday M A K, Martin J R, 1993 Writing Science: Literacy and Discursive Power (Falmer Press, London)

Harlan S, Brazel A, Jenerette G, Jones N, Larsen L, Prashad L, Stefanov W, 2008, "In the shade of affluence: the inequitable distribution of the urban heat island" Research in Social Problems and Public Policy 15 173-202

Hastings A, 1999, “Analysing power relations in partnerships: is there a role for discourse analysis?" Urban Studies 36 91-106

Hennessy K B, Fitzharris B C, Bates N, Harvey S M, Howden L, Hughes L, Salinger J, Warrick R, 2007, "Australia and New Zealand", in Climate Change: Impacts, Adaptation and Vulnerability. Contribution of Working Group II to the Fourth Assessment Report of the Intergovernmental Panel on Climate Change Eds M L Parry, O F Canziani, J P Palutikof, P J van der Linden, C E Hanson, (Cambridge University Press, Cambridge) pp 507-540

Hillier J, 1999, "What values? Whose values?" Ethics, Place, Environment 2 179-199

Hobson K, 2006, "Bins, bulbs, and shower timers: on the 'techno-ethics' of sustainable living" Ethics, Place and Environment 9 317-336

Howes M, McKenzie M, Gleeson B, Gray R, Byrne J, Daniels P, 2010, “Adapting ecological modernisation to the Australian context" Journal of Integrative Environmental Sciences 7 5-21

Hughes L, 2011, "Climate change and Australia: key vulnerable regions" Regional Environmental Change 11 (Supp. 1) s189-s195

Iedema R, Grant S, 2004, “AIMS retrieval medicine incident reporting: an investigation of reporters' expressions of attitude and feeling", University of New South Wales, Centre for Clinical Governance Research, Sydney, http://www.med.unsw.edu.au/medweb.nsf/resources/Projects4/\$file/AIMS.pdf

Ikeme J, 2003, "Equity, environmental justice and sustainability: incomplete approaches in climate change politics" Global Environmental Change 13 195-206

IPCC, 2007, "Impacts, adaptation and vulnerability", Intergovernmental Panel on Climate Change Working Group II Report, United Nations, New York 
Jacobs K, 2004, "Waterfront redevelopment: a critical discourse analysis of the policy-making process within the Chatham maritime project" Urban Studies 41 817-832

Jessop B, Oosterlynck S, 2008, "Cultural political economy: on making the cultural turn without falling into soft economic sociology" Geoforum 39 1155-1169

Keil R, Desfor G, 2003, "Ecological modernisation in Los Angeles and Toronto" Local Environment $827-44$

Kelly P, Adger W, 2000, "Theory and practice in assessing vulnerability to climate change and facilitating adaptation" Climate Change 47 325-352

Kerr R A, 2008, "Climate change hotspots mapped across the United States" Science 321909

Kretzmann J P, McKnight J L, 1993 Building Communities from the Inside Out: A Path Toward Finding and Mobilizing a Community's Assets Institute for Policy Research, Evanston, IL

Kumar S, Pallathucheril V G, 2004, "Analyzing planning and design discourses" Environment and Planning B: Planning and Design 31 829-846

Liverman D, 2009, "Preface" in "Suffering the science: climate change, people and poverty", Oxfam Briefing Paper 130, Oxfam International, http://www.oxfam.org/sites/www.oxfam.org/files/bp130-suffering-the-science.pdf

Lucas K, 2006, "Providing transport for social inclusion within a framework for environmental justice in the UK" Transportation Research, Part A 40 801-809

MacCallum D, 2008, "Participatory planning and means-ends rationality: a translation problem" Planning Theory and Practice 9 325-343

MacCallum, D, 2009 Discourse Dynamics in Participatory Planning: Opening the Bureaucracy to Strangers (Ashgate, Aldershot, Hants)

MacCallum D, Hopkins D, 2011, "The changing discourse of city plans: rationalities of planning in Perth, 1955-2010" Planning Theory and Practice 12 485-510

MacCallum D, Steele W, Byrne J, Houston D, 2011, "Environmental imaginaries: climate change as an object of urban governance", State of Australian Cities, Melbourne, November

Marcuse P, Connelly J, Novy J, Olivo I, Potter C, Steil J (Eds), 2009 Searching for the Just City: Debates in Urban Theory and Practice (Routledge, London)

Marsden Jacob and Broadleaf Capital International, 2009, "Redland City Council Climate Change Risk Assessment and Adaptation Plan", Redland City Council, Cleveland, QLD, http://www.redland.qld.gov.au/SiteCollectionDocuments/Plans_Reports/Management_Plans/ ClimateChangeRiskAssessmentAdaptationPlan.pdf

Martin J R, 2004, "Positive discourse analysis: solidarity and change" Revista Canaria de Estudios Ingleses 49 179-201

Mathie A, Cunningham G, 2003, "From clients to citizens: asset-based community development as a strategy for community-driven development" Development in Practice 13 474-486

Maunsell Australia, 2007, "Climate Change and Energy Taskforce final report: a call for action", Brisbane City Council, Brisbane

Mendelsohn R, Dinar A, Williams L, 2006, "The distributional impact of climate change on rich and poor countries" Environment and Development Economics 11 159-178

Mills S, 1997 Discourse (Routledge, London)

Mol A P J, Sonnenfeld D A, 2000, "Ecological modernisation around the world: an introduction" Environmental Politics 9 3-14

Moss, J (Ed.) 2009 Climate Change and Social Justice (Melbourne University Press, Melbourne)

Moulaert F, Martinelli F, Swyngedouw E, Gonzalez S, 2005, "Towards alternative models, of local innovation" Urban Studies 42 1969-1990

Muntigl P, Weiss G, Wodak R, 2000 European Union Discourses on Un/employment: An Interdisciplinary Approach to Employment Policy-making and Organizational Change (John Benjamins, Amsterdam)

Myerson G, Rydin Y, 1996 The Language Of Environment: A New Rhetoric (UCL Press, London)

Nelson V, Meadows K, Cannon T, Morton J, Martin A, 2002, "Uncertain predictions, invisible impacts, and the need to mainstream gender in climate change adaptations" Gender Development 10 51-59

Nicholson T, 2007 Equity in Response to Climate Change Roundtable (Brotherhood of St Lawrence, Melbourne) 
Nyong A, Adesina F, Osman Elasha B, 2007, "The value of indigenous knowledge in climate change mitigation and adaptation strategies in the African Sahel" Mitigation and Adaptation Strategies for Global Change 12 787-797

O’Brien K, Eriksen S, Nygaard L P, Schjolden A, 2007, "Why different interpretations of vulnerability matter in climate change discourses" Climate Policy 7 73-88

Office of Climate Change, 2008 Climate Change in Queensland: What the Science is Telling Us Queensland Government, Brisbane

Paolisso M, Douglas E, Enrici A, Kirshen P, Watson C, Ruth M, 2012, "Climate change, justice, and adaptation among African American communities in the Chesapeake Bay Region" Weather, Climate and Society 4 34-47

Patz J A, Kovats R S, 2002, "Hotspots in climate change and human health" British Medical Journal 325 1094-1096

Pelling M, High C, Dearing J, Smith D, 2008, "Shadow spaces for social learning: a relational understanding of adaptive capacity to climate change within organisations" Environment and Planning A 40 867-884

Pietsch J, McAllister I, 2010, “A diabolical challenge: public opinion and climate change policy" Environmental Politics 19 217-236

Portugali J, Alfasi N, 2008, “An approach to planning discourse analysis" Urban Studies 45 251-272

Queensland Government, Brisbane

2009a ClimateQ: Toward a Greener Queensland

2009b South East Queensland Climate Change Management Plan: Draft for Public Consultation 2009c South East Queensland Regional Plan 2009-2031

2011, "Climate change: adaptation for Queensland", Issues Paper

Redland City Council, Cleveland, QLD

2010a, "Confronting our climate future"

2010b, "2030 Community Plan"

2010c, "Community engagement policy", Corporate Pol-3053, http://www.redland.qld.gov.au/SiteCollectionDocuments/Policies/POL-3053.pdf

Redland Shire Council, 2003, "Local Greenhouse Action Plan”, Redland City Council, Cleveland, QLD

Richardson T, Jensen O B, 2003, "Linking discourse and space: towards a cultural sociology of space in analysing spatial policy discourses" Urban Studies 40 7-22

Rutland T, Aylett A, 2008, "The work of policy: actor networks, governmentality and local action on climate change in Portland, Oregon" Environment and Planning D: Society and Space $25627-646$

Rydin Y, Pennington M, 2000, "Public participation and local environmental planning: the collective action problem and the potential of social capital" Local Environment 5 153-169

Sandercock L, 1998 Towards Cosmopolis: Planning for Multicultural Cities (John Wiley, Chichester, Sussex)

Steele W, 2010, "Securing the Australian city: what is the national adaptation role in a climateconstrained future?", Issues Paper 14, Urban Research Program, Griffith University, Brisbane, http://www.griffith.edu.au/_data/assets/pdf_file/0008/246716/urp-ip14-steele-2010.pdf

Steele W, Gleeson B, 2010, "Planning in climate change", in A Climate for Growth: Planning SouthEast Queensland (University of Queensland Press, Brisbane) pp 108-123

Steele W, Gleeson B, 2011, "The great risk shift: the securitization of Australian housing" Housing Studies 26 235-250

Steele W, MacCallum D, Byrne J, Houston D, 2012, "Planning the climate-just city" International Planning Studies 17 67-83

Stibbe A, 2001, "Language, power and the social construction of animals" Society and Animals $9145-161$

Sum N L, 2011 Towards a Cultural Political Economy (Edward Elgar, Cheltenham, Glos)

Tett A, Wolf J M, 1991, "Discourse analysis and city plans" Journal of Planning Education and Research 10 195-200 
Throgmorton J A, 1996, "Impeaching' research: planning as persuasive and constitutive discourse", in Explorations in Planning Theory Eds S J Mandelbaum, L Mazza, R W Burchell (Center for Urban Policy Research, Rutgers, The State University of New Jersey, New Brunswick, NJ) pp 345-364

Throgmorton J A, 2000, "On the virtues of skillful meandering: acting as a skilled-voice-in-the-flow of persuasive argumentation" Journal of the American Planners Association 66 367-379

van Leeuwen T, 1993, "Genre and field in cricital discourse analysis: a synopsis" Discourse and Society 4 193-223

Walker G, 2009, "Globalizing environmental justice” Global Social Policy 9 355-382

Weiss G, Wodak R (Eds) 2003 Critical Discourse Analysis: Theory and Interdisciplinarity (Palgrave Macmillan, Basingstoke, Hants)

Welford R, Hills P, 2004, "Ecological modernisation, environmental policy and innovation priorities for the Asia Pacific Region" International Journal of Environment and Sustainable Development $2324-340$

Wilson S M, Richard R, Joseph L, Williams E, 2010, "Climate change, environmental justice, and vulnerability" Environmental Justice 3 13-19

Wodak R, 2009 The Discourse of Politics in Action: Politics as Usual (Palgrave Macmillan, Basingstoke, Hants)

Young I M, 1990 Justice and the Politics of Difference (Princeton University Press, Princeton, NJ)

Young I M, 2000 Inclusion and Democracy (Oxford University Press, Oxford)

Zahran S, Brody S D, Vedlitz A, Grover H, Miller C, 2008, "Vulnerability and capacity: explaining local commitment to climate-change policy" Environment and Planning C: Government and Policy 26 544-562 